\begin{tabular}{l|c|c}
\hline ISSN: 0001-5113 & ACTA ADRIAT., & ORIGINAL SCIENTIFIC PAPER \\
AADRAY & $60(1): 79-86,2019$ & \\
\hline
\end{tabular}

\title{
Characteristics of the Croatian anchovy purse seiner fleet
}

\author{
Alen SOLDO ${ }^{*}$, Neven BOSNIĆ ${ }^{1}$ and Vice MIHANOVIĆ ${ }^{2}$ \\ ${ }^{1}$ Department of Marine Studies, University of Split, Croatia \\ ${ }^{2}$ Faculty of Maritime Studies, University of Split, Croatia \\ *Corresponding author, email: soldo@unist.hr
}

\begin{abstract}
Croatia has a fishing fleet of 7559 vessels. Of these, small-scale coastal fishing boats, less than 12 meters in length, makes up 95,7\% of the fleet. However, the largest percentage of catches, more than 94\%, is made by purse-seiners that are representing only 3\% of total fishing vessels. These vessels target small pelagic fish, predominately sardine and anchovy. This paper describes all the technical characteristics of the Croatian purse seiner fleet, based on 113 purse seine vessels registered in 6 Croatian ports and targeting anchovy in order to allow a precise determination of that fleet fishing capacity and subsequent management of the fleet in a responsible and sustainable manner. Comparison of different technical characteristics showed that the length of a vessel corresponds to the amount of the catch as well as to size of the fish. Hence, results confirm superiority of sonar, as a fish-finding device, over sounder in detecting fish shoals, which is prerequisite for purse seine fishing.
\end{abstract}

Key words: purse seiner; fleet capacity; sonar; anchovy; fishing power

\section{INTRODUCTION}

Purse seiners comprise a large group of fishing vessels appearing in all sizes and ranging from small boat to open ocean-going vessels. These vessels are the most important and most effective vessels to catch aggregating species near the surface using purse seine. Purse seine is a fishing gear defined as a long wall of netting framed with floatline and leadline (usually, of equal or longer length than the former) and having purse rings hanging from the lower edge of the gear, through which runs a purse line made from steel wire or rope which allow the pursing of the net. For most of the situation, it is the most efficient gear for catching large and small pelagic species that is shoaling. The vessel surrounds the shoal with a purse seine and then the bottom of the net is pursed (closed) underneath the shoal by hauling a wire, which runs from the vessel through rings on the bottom of the net, and back to the vessel. Searching for shoals and assessing the size and direction of movement of it are the most important part of the fishing operation. To assist in fish detection, sometimes crows nests are arranged on masts and on large vessels observation towers and helicopter landing decks are provided (FAO, 1985; CETINIĆ \& SOLDO, 2010).

Fishing vessels using purse seines are equipped with pursing gallows and pursing winches for hauling the purse lines which close 
the net after setting. From the viewpoint of deck arrangement three main types of one boat purse-seiners can be distinguished: The North American type, the European type and the Drum seiner. North American type purse - seiners are characterized by the bridge and accommodation placed forward. The power block is slung from a derrick attached to the mast behind the wheel house. The winch is usually fitted to the parallel drums and is situated opposite the pursing gallows. The net is carried at the stern of the vessel. European type purse seiners have the bridge and accommodation located aft. The fish hold is situated amidships. The net is carried on the upper deck and power block is fitted to the side of the bridge. The pursing winch is normally situated forward with the drums facing the pursing davit. The Drum seiner type has the same basic layout as an American seiner with the exception that a drum is used instead of a power block. This technology is mainly used in Canada and U.S.A. Apart of these three main types a special distinction is made for Tuna purse seiners, which are considered as a sub-group of the North American type as they share the same general arrangement but they are much larger, and equipped to handle very large and heavy purse seines for tuna. Hence, they are normally equipped with an auxiliary boat called skiff. The deck equipment consists of a three drum purse seine winch and a heavy boom and net. A crow's nest is placed at the top of the mast. The search for tuna schools is often carried out by a helicopter, for which a landing platform is provided (FAO, 1985; CETINIĆ \& SOLDO, 2010).

In total, Croatia has 7559 vessels in its fishing fleet with an average age of 35 years. Of these, small-scale coastal fishing boats, less than 12 meters in length, makes up 95,7\% of the fleet. However, the largest percentage of catches, more than $94 \%$, is made by purse-seiners that are representing only $3 \%$ of total fishing vessels. These vessels target small pelagic fish, predominately sardine and anchovy. Within total catch of 69475 tons, small pelagic makes 65335 tons (sardine $48420 \mathrm{t}$ and anchovy 10883 tons, respectively) (CBS, 2018).
In terms of fishing effort management, the vessels fishing actively for small pelagic have a limit of activity of 20 days per month with a total maximum of 180 days per year, with an additional 144 days for vessels specifically targeting anchovies. As fishing effort management is a combination of limitations to the fleet capacity and the amount of time that can be spent at sea by that fleet it is essential to have knowledge on characteristics of a particular fishing fleet in order to define instruments for effective and successful management.

Each set of capacity management instruments has to be tailored to the characteristics of a specific fishing fleet. A distinction should be made between those instruments physically limiting capacity (technical measures, limitations on engines, vessel size, gear restrictions) and those instruments limiting the deployment of the capacity (effort restrictions, catch restrictions). For those instruments limiting overall capacity, it should be noted that over time, for example as a result of technological development, the fishing capacity of the remaining physical capacity can alter (VAN HOOF, 2010).

In fisheries, the term 'capacity' is related to several issues that reflect the relationship between the concept of capacity, the harvesting of fish by fishing vessels, and the biological concept of fishing mortality. In technical terms, fishing capacity relates to the "fishing power" of a vessel; "capacity" than includes gear size, boat size and engine capacity. A difficulty with such a physical definition is that it focuses on the inputs used to catch fish rather than the output of fish and fishing effort and may create a misleading impression of what is happening to true capacity. For instance, where engine power is controlled, fishers can increase the power of their vessels in other ways, thereby substituting one input for another and increasing capacity in the fishery (VAN HOOF, 2010).

Thus, the aim of present study is to describe all the technical characteristics of the Croatian purse seiner fleet targeting anchovy in order to allow a precise determination of that fleet fishing capacity. 


\section{MATERIAL AND METHODS}

Research has been conducted in the central and southern Adriatic, the area described by GFCM (General Fisheries Commission for the Mediterranean) as geographic subregion GSA 17. It started in January 2003 and continued over the years with focus on different aspects until 2015. The landings of the fishing fleet have been monitored at 33 fishing harbors. The research was based on 5906 catch records available, containing information on the time, location, catch weight, species size and composition of every catch made by the 113 purse seine vessels. Most of the purse seiners were longer than $15 \mathrm{~m} \mathrm{LOA}$, while only 3 were between 10 and $15 \mathrm{~m}$. Different technical characteristics of those vessels have been obtained and compared to achieved catches of anchovy in order to determine similar categories within purse seine fleet and impact of a certain vessel characteristic on a vessels fishing ability.

\section{RESULTS}

Average length of purse seiners was $21.59 \mathrm{~m}$ LOA, within the smallest has $10.9 \mathrm{~m}$ and longest $31.40 \mathrm{~m}$. Regarding gross tonnage results show that an average is $73.35 \mathrm{GT}$, while the range is from 7.39 GT to 183 GT. Average engine power is $297 \mathrm{~kW}$ with smallest engine of $54 \mathrm{~kW}$ and strongest of $625 \mathrm{~kW}$. The majority of the fleet was registered in Zadar port, followed by Split and Rijeka, while only 5 vessels were registered in Pula port, and 4 in Šibenik and Dubrovnik.

CETINIĆ \& SOLDO (2010) determined that Croatian fishing fleet was built by use of various construction materials, ranging from traditional wood, steel and glass reinforced plastic (GRP) to ferrocement and aluminum. However, as purse seiners are specific fishing vessels, this research showed that the majority of the purse seiners vessel have been built by wood (63\%), followed by GRP (22\%) and steel (15\%).

As the main goal of this paper was to determine the impact of vessel's technical characteristics (LOA, GT, engine power, hull material) on fishing ability, anchovy catches have been

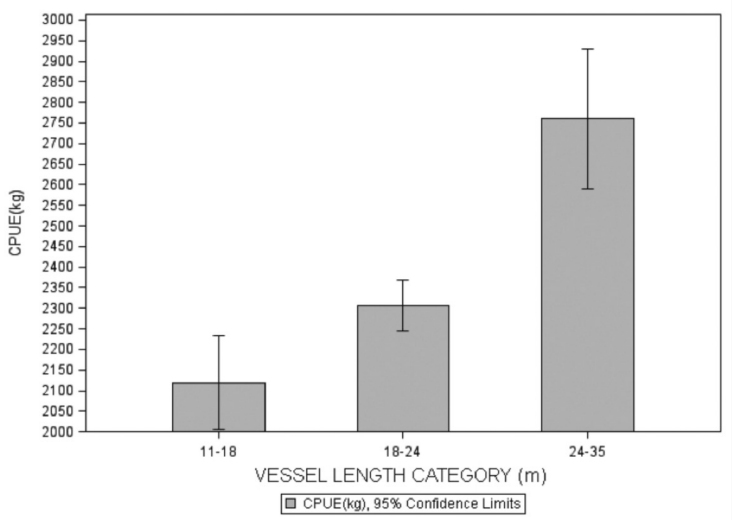

Fig. 1. Comparison of average CPUE (catch per unit effort) obtained in different vessel categories.

compared to the different vessel's characteristic. Thus, it has been noted that major characteristic influencing the amount of catch (CPUE- catch per unit effort) is length of a particular vessel (Fig. 1). Vessels larger than $24 \mathrm{~m}$ are usually obtaining catches $30.22 \%$ larger than vessels smaller of $18 \mathrm{~m}$. Hence, comparison of the main characteristics of vessels within these length categories show that vessels smaller than $24 \mathrm{~m}$ LOA are dominantly made by wood with relatively higher share of GRP vessels in category 18-24 m. Vessels larger than $24 \mathrm{~m}$ are mainly made of steel and equipped with sonars as fish finding device, compared to smaller categories which dominantly use sounder (Table 1).

Obtained results show that the length of the vessels also corresponds to the average size of the anchovy (Fig. 2). Usually, the size of the small pelagic fish is described by a number of fish specimens in one kilogram (No per $\mathrm{kg}$ ), with lower number meaning a bigger fish.

To determine other characteristics influencing fishing ability, catch characteristic (CPUE and average anchovy size) of different vessels have been compared. Results show that vessels registered in the same port have similar catches. There is a significant difference between vessels of different ports (ANOSIM; $\mathrm{R}=0.357 ; \mathrm{p}=$ 0.01 ) with highest difference detected between Dubrovnik port (as the most southern) and others (Fig. 3).

Another important characteristic of the purse seiner is its equipment with fish finding devices. 
Table 1. Fish finder equipment, number of sets, total catch, average CPUE (catch per unit effort) for different vessel category characterized by average length, average GT, average engine power, hull material (W-wood, $S$-steel, GRP) and fleet share.

\begin{tabular}{|c|c|c|c|c|c|c|c|c|c|c|c|c|}
\hline \multirow{2}{*}{$\begin{array}{l}\text { Length } \\
\text { category } \\
\text { (m) }\end{array}$} & \multirow{2}{*}{$\begin{array}{l}\text { Average } \\
\text { length } \\
(\mathrm{m})\end{array}$} & \multirow{2}{*}{$\begin{array}{c}\text { Average } \\
G T\end{array}$} & \multirow{2}{*}{$\begin{array}{c}\text { Average } \\
\text { engine } \\
k W\end{array}$} & \multicolumn{3}{|c|}{ Hull material (\%) } & \multirow{2}{*}{$\begin{array}{c}\text { Sounder } \\
\%\end{array}$} & \multirow{2}{*}{$\begin{array}{c}\text { Sonar } \\
\%\end{array}$} & \multirow{2}{*}{$\begin{array}{c}\text { Fleet } \\
\text { share } \\
\%\end{array}$} & \multirow{2}{*}{$\begin{array}{l}\text { No. of } \\
\text { sets }\end{array}$} & \multirow{2}{*}{$\begin{array}{c}\text { Total } \\
\text { catch }(\mathrm{kg})\end{array}$} & \multirow{2}{*}{$\begin{array}{c}\text { Average } \\
\text { CPUE } \\
(\mathrm{kg})\end{array}$} \\
\hline & & & & $\mathrm{W}$ & $\mathrm{S}$ & GRP & & & & & & \\
\hline$<18$ & & & 175,50 & & & & & & 16,5 & 971 & & 2119 \\
\hline $18-24$ & & & & 75,51 & & 22, & & 26,5 & 53,8 & 4168 & 9609735 & 2305,60 \\
\hline$>24$ & 26,11 & 9,18 & 406,93 & 33,33 & 62,96 & 3,70 & 96,30 & 55,56 & 29,7 & 769 & 2122564 & 2760,1 \\
\hline
\end{tabular}

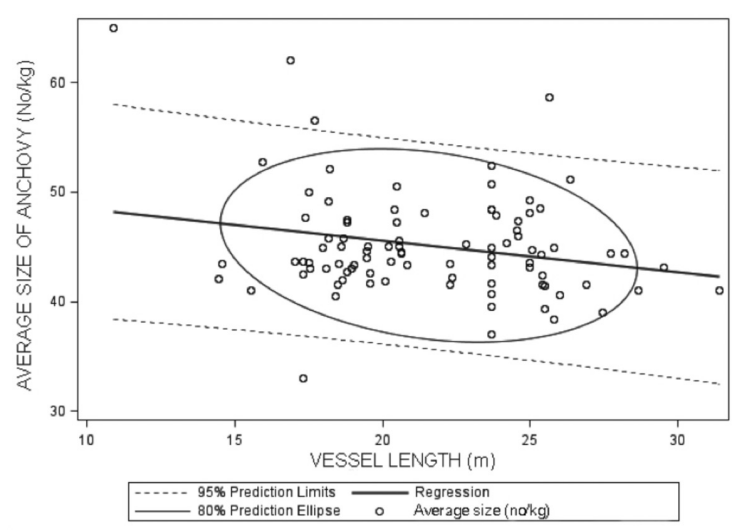

Fig. 2. Comparison of the vessel length (in meters) to average size of anchovy (No. of specimens in $\mathrm{kg}$ ).

Most of the fishing vessels are using some kind of fish finding device, usually sounder. However, as sounder detects fish directly beneath the vessel, it is not suitable for finding fish in shallow waters as well as on a certain horizontal distance from a vessel during search for shoals of fish. Thus, in purse seining a use of sonar is more suitable for locating fish around a vessel, but some fishermen are reluctant to equip their vessels with it due to the considerably higher cost compared to sounder. Such situation is especially noticeable within category of vessels, predominantly wooden, less than $18 \mathrm{~m}$, where

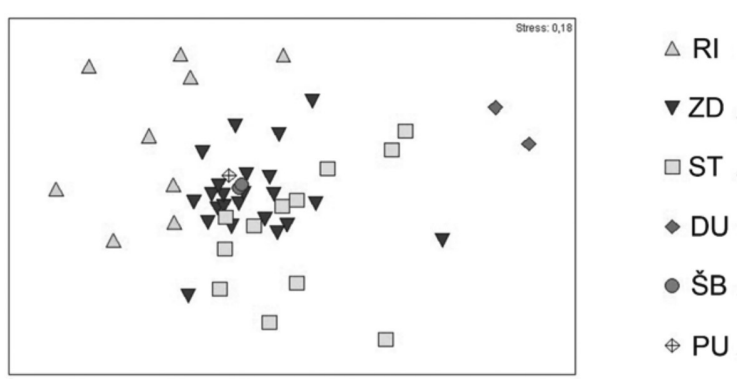

Fig. 3. Multi-Dimensional Scaling diagram od similarities between catches of vessels categorized by port of registration (RI-Rijeka, ZD-Zadar, ST-Split, DUDubrovnik, $\breve{S} B$-Šibenik, PU-Pula).

cost share of sonar is significantly higher than in category of vessels larger than $24 \mathrm{~m}$ and made of steel (Table 1). Moreover, the highest share of vessels equipped with sonars was registered in Rijeka port $(81.25 \%$ of purse seiners from Rijeka have sonar), while none of vessels registered in Dubrovnik have been equipped with it. In general, out of vessels investigated during this research 92,3\% were equipped with sounder, while only $31.9 \%$ have sonar. In order to determine a difference between use of sounder or sonar the analysis of catches obtained within a similar vessels size category equipped by different fish finding devices was performed. To exclude the impact of other vessels charac-

Table 2. Comparison of catches by similar vessels using sonar or sounder.

\begin{tabular}{ccccccccc}
\hline $\begin{array}{c}\text { Fish Finding } \\
\text { Device }\end{array}$ & $\begin{array}{c}\text { No. of } \\
\text { vessels }\end{array}$ & $\begin{array}{c}\text { Average } \\
\text { length }(\mathrm{m})\end{array}$ & $\begin{array}{c}\text { Average } \\
G T\end{array}$ & $\begin{array}{c}\text { Average } \\
\text { engine } \\
(\mathrm{kW})\end{array}$ & $\begin{array}{c}\text { No. of } \\
\text { hauls }\end{array}$ & $\begin{array}{c}\text { Average } \\
\text { CPUE }(\mathrm{kg})\end{array}$ & $\begin{array}{c}\text { Std. Dev. } \\
\text { Coeff. } \\
\text { Var. (\%) }\end{array}$ \\
\hline SONAR & 18 & 23,60 & 106,5 & 398,31 & 840 & 2947,33 & 831,32 & 28,21 \\
\hline SOUNDER & 25 & 23,54 & 95,31 & 357,31 & 2264 & 1998,67 & 522,94 & 26,16 \\
\hline
\end{tabular}


teristics, total of 43 vessels with a similar length (average $23.5 \mathrm{~m}$ ) were investigated of which 25 and 18 were equipped by echo sounder and sonar, respectively. Obtained results showed a statistically significant difference in CPUE, as sonar equipped vessels are catching $47.46 \%$ more per set than echo sounder vessels (average CPUE $2947.33 \mathrm{~kg}$ and $1998.67 \mathrm{~kg}$ per set, respectively) (Table 2).

\section{DISCUSSION}

The base of all management measures is a fishing unit and there are three types of fishing units: the fleet, the fishery and the métier (ICES, 2003). A fleet is as a physical group of vessels sharing similar characteristics in terms of technical features and/or major activity. A fishery is a group of vessel voyages targeting the same (assemblage of) species and/or stocks, using similar gear, during the same period of the year and within the same area. Finally, a métier is a homogeneous sub-division, either of a fishery by vessel type, or of a fleet by voyage type. Several methods may be considered to identify fleets and métiers. In this paper, a fleet segment is defined as a group of vessels with the same length class (LOA) and predominant fishing gear during the year (IRIONDO et al., 2012). The landing information (CPUE and size of anchovy) was used to define métier, thus, the output-based approach was applied. It assumes that landing profiles reflect fishing intention. The approach used consists of conducting analyses of landing profiles and then grouping fishing trips of similar landing profile into métiers.

Comparison of different technical characteristics of purse seiners showed that the length of a vessel corresponds to the amount of the catch. The dominant impact of the length derives from the working deck surface, which is related to the size of a purse seine net as the larger net surrounds larger and deeper area, thus providing higher probability for obtaining bigger catch.

Obtained results shows that a longer vessel, with a higher and longer purse seine, is fishing a bigger fish, which coincide with a data that bigger anchovy usually occupies a deeper water than a small size specimens (SINOVČIĆ, 2000). It has to be noted that a bigger fish usually corresponds to a higher price per $\mathrm{kg}$, so higher catch of bigger fish means higher profit, which is reason why fishermen are trying to target bigger fish.

With regards to use of sonar, results confirm its superiority over sounder in detecting fish shoals, which is prerequisite for purse seine fishing. Use of sonar is especially important in shallow waters and that is exactly a main reason why purse seiners from northern shallow Adriatic (Rijeka port particularly) are dominantly using sonars. The number of vessels equipped with sonars is decreasing toward south of Adriatic as the sea depth is increasing, while the most southern port Dubrovnik has no registered vessels equipped with sonar as they operate in the deepest part of Adriatic. However, this also point to the traditional manner of purse seine fishing in Central and South Adriatic where fishermen are usually focused on traditionally known fishing grounds in comparison to the Northern Adriatic where fishermen are paying attention on a modern technology due to the absence of traditional fishing grounds (fishing of small pelagic in Northern Adriatic was previously performed mainly by pelagic trawlers). Hence, results also show that, in general, technical characteristics of purse seiners are related to the ports of vessel registration. That probably originates from differences between fishing grounds as vessels are built or purchased according to the usual purse seine techniques that are existing in certain areas, geographical conditions, as well as different final consumers (tuna farms, canning factories, salt-fish factories, export, etc.) which require specific conditions of a catch.

Evolution of the Croatian modern purse seiner fleet is evident, especially when it is compared to the vessel characteristics of a fleet from the period 1963-78 (ALEGRIA-HERNANDEZ, 1983). According to the data from that period the largest purse seiners of that time were 24.6-25.8 $\mathrm{m}$ long with 98-109 GT and engine power from 176-294 kW. Most of these vessels are active in fishing even nowadays, but they are not anymore the largest as today they are considered as 
medium sized purse seiners. The most significant difference is in engine power as in period 1963-78 the largest vessel had $293 \mathrm{~kW}$ while today an average of a whole fleet is $297 \mathrm{~kW}$ with strongest of $625 \mathrm{~kW}$. Such difference can be explained by a change in fishing activities as nowadays largest purse seiners are not only involved in fishing of small pelagic fish, but they target also tunas where fishing technique requires a fast vessel speed (CETINIĆ \& SOLDO, 2010).

Regulating fleet capacity and fishing activity and adjusting them to the level of sustainable exploitation of marine resources is a major objective of the Common Fisheries Policy
(REGULATION, 2013). A clear understanding of fishing fleet dynamics is essential to reach this objective (ULRICH \& ANDERSEN, 2004), in particular knowledge of vessel characteristics and techniques used in relation to target species. These results show that fishing capacity and fishing power of a purse seiner fleet can not be calculated purely by using the number of vessels involved in fisheries as in that way the real effect of the fleet on targeted species would surely be underestimated, and consequently that would lead to over-exploitation of a stocks Thus, it is necessary to take into account all the characteristics of the fleet in order to manage it rationally and in accordance to the policy for sustainable and responsible fisheries.

\section{REFERENCES}

ALEGRIA-HERNÁNDEZ, V. 1983, Assessment of pelagic fish abundance along the eastern Adriatic coast with special regard to sardine (Sardina pilchardus Walb.) population. Acta Adriat., 24 (1/2): 55-95.

CBS. 2018. Fishery, 2017. Croatian Bureau of Statistics. First release 1.4.1.

REGUlation. 2013. Regulation (EU) No $1380 / 2013$ of the European Parliament and of the Council of 11 December 2013 on the Common Fisheries Policy, amending Council Regulations (EC) No 1954/2003 and (EC) No 1224/2009 and repealing Council Regulations (EC) No 2371/2002 and (EC) No 639/2004 and Council Decision 2004/585/EC. OJ L 354 , 28.12.2013: 22-61.

CETINIĆ, P. \& A. SOLDO. 2010. Ribarski brod i luka: tehnologija iskorištavanja (Fishing boat and port: technology of exploitation). Udžbenici Sveučilišta u Splitu, Književni krug, Pomorska biblioteka, 492 pp.

FAO, 1985. Definition and classification of fishery vessel types. FAO fisheries technical paper no. 267.
ICES. 2003. Report of the Study Group for the development of fishery-based forecasts. ICES Document CM 2003, ACFM:08 Ref. D.

IRIONDO, A., R. PRELLEZO, M. SANTURTÚN, D. GARCÍA, I. QUINCOCES \& E. MUGERZA. 2010. A multivariate approach for metier definition: A case study of Basque Country trawlers. Revista de Investigación Marina 17(6): 139-148.

SINOVČIĆ, G. 2000. Anchovy, Engraulis encrasicolus (Linnaeus, 1758): Biology, population dynamics and fisheries case study. Acta Adriatica Vol. 41 (1): 3-53.

ULRICH C., B.S. ANDERSEN. 2004. Dynamics of fisheries, and the flexibility of vessel activity in Denmark between 1989 and 2001, ICES Journal of Marine Science, vol. 61: 308-322.

VAN HOOF, L. 2010. Tools for Fishing Fleet Management. European Parliament study, Directorate General for Internal Policies, Policy Department B: Structural and Cohesion Policies - Fisheries. 


\title{
Karakteristike hrvatske ribarske flote za lov inćuna
}

\author{
Alen SOLDO, Neven BOSNIĆ i Vice MIHANOVIĆ
}

\begin{abstract}
SAŽETAK
Hrvatska ribarska flota se sastoji od 7559 plovila. Od toga, brodice za priobalni ribolov, manje od 12 m dužine, čine 95,7\% flote. Nasuprot tome, najveći udio u ukupnom ulovu, više od 94\%, ostvaruju plivaričarski brodovi koji čine tek 3\% od ukupnog broja plovila. Plivaričarska plovila ciljaju prvenstveno malu plavu ribu, uglavnom srdelu i inćuna. Ovaj rad opisuje tehničke karakteristike hrvatske plivaričarske flote na osnovu istraživanja ukupno 113 plovila registriranih u 6 hrvatskih ribarskih luka, koji ciljaju inćuna, a s ciljem preciznijeg određivanja ribarskog kapaciteta plivaričarske flote, a posljedično i upravljanja tom flotom na odgovoran i održiv način. Usporedba različitih tehničkih karakteristika brodova je pokazala da je dužina plovila u izravnoj korelaciji s količinom ostvarenog ulova po plovilu, a također i s veličinom lovljene ribe. Rezultati su također pokazali da je sonar, kao uređaj za traženje ribe, značajno efikasniji od eho-sondera, u traženju jata riba, što je osnova tehnike plivaričarskog ribolova.
\end{abstract}

Ključne riječi: brodice za priobalni ribolov; kapacitet flote; sonar; brljun 
